\title{
General Election In Indonesia
}

\author{
Ardiansyah \\ Departemen of Constitutional Law \\ Islamic University of Riau \\ Pekanbaru, Indonesia \\ Email: ardiansyah@law.uir.ac.id
}

\begin{abstract}
Elections are a process of electing people to fill certain political positions, such as presidents, vice presidents, people's representatives at various levels of government, to the simplest or the least of the village heads. From the perspective of Constitutional Law, direct popular vote is conducted within the period of office in an organization of the state. On that basis, then speaking of the election, inevitably must be placed within the framework of the principle of people's sovereignty, because the election itself is a manifestation of people's participation that is central to the principle of people's sovereignty or democracy. Election is a means of political participation of the community to participate in determining public policy. Through elections the people can directly establish public policy through support to contestants who have programs that are considered aspirational to the interests of the people. Contestants who win because they are supported by the people must realize their promises when they have held the reins of government.
\end{abstract}

\section{Keywords - Elections, political, democracy}

\section{Introduction}

General Election is an important milestone in the transition to a democracy. Elections provide an opportunity to test how a set of institutions function in transition, and whether fundamental human rights are protected and nurtured. A very important measure in this process is whether citizens believe they are free to exercise their rights to express political opinions, associate, assemble and move as part of an electoral process.

Testing whether elections are free and fair includes not only whether the electoral organizers are impartial and effective, but also whether candidates can campaign freely for popular support. The test should also consider whether government resources are properly utilized in the electoral process whether the military is neutral and acts as a professional organization; whether police and prosecutors maintain order and protect those who wish to exercise their civil and political rights, whether the judiciary is impartial and effective, and whether the media freely transmit accurate information and acts as a watchdog against government and the political process, and whether media providing access to candidates and objective coverage of the candidates.

Elections must be tested in the context of a broader transition of a country to a democracy, not as an isolated event. An important element in this process is the building of public confidence in elections. If citizens do not feel that they are free to make political choices, get enough information to do so, and their choice will be respected, the election process will not be really meaningful. Candidates must feel they have a fair chance to win votes that there is a "flat playing field" to encourage them to participate in the process, and to respect the outcome of the election. It is also important for the community that they can believe in the election results. So the election is closely related to what preceded it and what happened afterwards.

In the democratic system to elect representatives of the people who will sit in the institutions of people's representatives, regional heads, as well as the president and vice president, as well as one form of fulfillment of citizens' rights in the political field. Elections are held to realize the sovereignty of the people. Because, people can not rule directly. Therefore, it is necessary to choose a representative of the people in order to govern a country for a certain period of time. Elections are conducted by adopting direct, public, free, confidential, honest, and fair principles.

In the General Election, voters in the General Election are also called constituents, and to them Election participants offer their promises and programs during the campaign period. Campaigns are held for a specified time, ahead of polling day. Election is one effort to influence people persuasively (not push) by doing activities of rhetoric, public relations, mass communication, lobby and other activities. Although agitation and propaganda in democracies are strongly criticized, but in election campaigns, agitation techniques and propaganda techniques are widely used by candidates or politicians are always political communicators.

Elections (elections) is the process of selecting people to fill certain political office positions. The positions are diverse, ranging from presidents, people's representatives at various levels of government, to village heads. In the broader context, elections can also mean the process of filling off positions like the OSIS chairman or class president, although for this the word 'election' is more often used.

Election is a means of political participation of the community to participate in determining public policy. Through elections the people can directly establish public policy through support to contestants who have programs that are considered aspirational to the interests of the people. 
Contestants who win because they are supported by the people must realize their promises when they have held the reins of government.

Elections According to Experts :

1. According to (Ramlan, 1992: 181) Election is defined as "the mechanism of selection and delegation or transfer of sovereignty to a trusted person or party.

2. According to Harris G. Warren and his colleagues, the election is: "Elections are the accostions when citizens choose their officials and cecide, what they want the government to do. ng these decisions citizens choose what rights they want to have and keep. "

3. According to Ali Moertopo the definition of General Elections as follows: "In essence, the election is a tool available for the people to run their sovereignty in accordance with the principles of the Preamble to the 1945 Constitution. Election itself is basically a Democratic Institute that elects members of the people's representatives in the MPR, the People's Legislative Assembly, the DPRD, which in turn has the duty to cooperate with the government, establish the politics and the course of state government ".

4. According to Suryo Untoro "That the General Election (hereinafter abbreviated as Election) is an election conducted by Indonesian citizens who have the right to vote, to elect their representatives sitting in the People's Legislative Assembly (Dewan Perwakilan Rakyat, DPR), Dewan People's Representatives of Level I and Level II (DPRD I and DPRD II) ".

In an election, there are at least three main systems that often apply, namely:

a. District System: The district system is the oldest system. This system is based on geographical unity. In a district system one geographic unit has one representative in parliament. This system is often used in countries with dualized systems, such as the United Kingdom and the United States.

b. Proportional representation system: In the proportional representation system, the number of seats in the DPR is divided into each political party, in accordance with the number of votes in the general election. specifically in the electoral district. For that purpose, then determined a consideration, for example 1 representative in the House of Representatives representing 500 thousand inhabitants.

c. Mixed systems: This system is a mixture of proportional district systems. This system divides the territory of the country into several electoral districts. The remaining votes of the voters are not lost, but are taken into account by the number of unassembled seats. This system was implemented in Indonesia since the 1977 election in electing members of DPR and DPRD. This system is also called proportional based on list stelsel.

Election Type :

1. Presidential and Vice Presidential Election. Since the 2004 election, the president or vice president are directly elected by the people. Previously, the president or vice president was elected by members of the DPR / MPR. Presidential and vice presidential election is the election to choose the pair of presidential candidates and vice presidents proposed by political parties or coalition of political parties in pairs, provided that:

a. The President and Vice President are elected in one spouse directly by the people.

b. A couple of candidates for President and Vice President shall be nominated by a political party or a coalition of political parties participating in the general election prior to the election.

c. A couple of candidates for President and Vice President who get a vote of more than fifty percent of the number of votes in the general election with at least twenty percent of the votes in each province spread over more than half of the provinces of Indonesia, constituted as President and Vice President

2. Election of Members of DPR, DPD and DPRD.

Based on the general provisions of Article 1 of Law Number 10 Year 2008 regarding General Election of Members of DPR, DPD and DPRD, the election of Members of DPR, DPD and DPRD is the election to elect members of DPR, DPD and Provincial DPRD and Regency / Municipal DPRD within the Unitary Republic State Indonesia based on Pancasila and the 1945 Constitution of the State of the Republic of Indonesia.

3. General Election of Regional Head and Deputy Regional Head.

The election of regional head and deputy regional head is the election to elect the candidate pair of regional head and deputy head of region proposed by political party or a combination of political parties and individuals. Since 2005, Pilkada has been held directly, both at the provincial and district / city levels. This arrangement is stipulated in Law Number 32 Year 2004 regarding Regional Government which states that "Regional Head and Deputy Regional Head are elected in one candidate pair which is carried out democratically based on the principle of direct, public, free, secret, honest and fair". Pilkada is included in the election regime after the enactment of Law Number 22 Year 2007 regarding General Election Organizer so that until now the General Election of Regional Head and Deputy Head of Region is better known as Pemilukada. In 2008, exactly after the enactment of Law Number 12 Year 2008 regarding the Second 
Amendment to Law Number 32 Year 2004 regarding Regional Government.

Elections can be done in two ways:

a. Direct method, in which people directly choose their representatives who will sit in representative bodies of the people. For example, elections in Indonesia to elect members of DPRD, DPR, and President.

b. The multilevel method, in which the people first elect their representatives (senate), then the people's representatives elect the people's representatives who will sit in the representative bodies of the people.

\section{Problems}

Elections are a "touchstone" on how institutions work in a country, and how respect for human rights, especially civil and political rights, is practiced. Elections can not be run in a vacuum; Elections must be seen in a social, historical and political context. In order for the elections to adequately reflect the will of the people, citizens should feel that they are free to exercise their rights, simply be informed of how they exercise that right and believe that the electoral process accurately reflects their choices. Based on the above problems, then the main subject in this paper is how the effort made for the election took place in a democratic way?

\section{Discussion}

Elections are not yet a measure of the sovereignty and will of the people already fulfilled. However, elections are, after all, the most basic form of political participation of citizens to determine the government and programs that are in accordance with their wishes, at least the government is also an acceptable program by the people. Sometimes the democracy adopted by a country is measured by the elections held by the country.

Elections are usually aimed at electing representatives of the people in Parliament, except in the royal state senate occasionally senate membership based on descent or appointment by the King or Queen. In a one-room state Parliament elects members of the People's Legislative Assembly and in similar presidential countries such as France, Egypt and Sri Lanka then elections are also to elect the President of the country.

The general election is a sign of the will of the people in a democracy, without any general election of a country which states that its state of democracy must not be a democratic state in the true sense. A country that holds general elections is not necessarily a truly democratic country, because it can still be questioned how many representatives of the People's Representative Council are directly elected by the people? is it less than lifted? or if all of them are selected. directly by the people, is still in question whether the principles of direct, general, free, secret and equitable elections can be implemented in the election? so it is no exaggeration if Maurice Duverger declares that where there is free and free election there is democracy.

In a democratic country, there is free elections andhonest is a necessity or absolute, meaning that which must exist and can not be limited, so be absolute sophistication. The necessity of election, to elect certain organizers will result in the election not merely indicating a relationship between the elect and the elected. Moreover, the election implies the relationship that the elected is accountable to the electorate. According to Belilante, no democratic government is not accountable to voters.

Because one form of people's political participation in a democratic government is the participation of members of the public in the general election, then in this political system the elections have several functions, as follows. First, elections are both an institution and an instrument for controlling the conflicts of interest that occur in society. Secondly, elections can also serve as a means to make a fair and peaceful change of government. Third, the general election in a broader sense, is a means to establish a basis of constitutional political legitimacy for the power to be built. Fourth, through the general election can also be seen the level of maturity and depth of national political culture that is socialized to the people during the past government period. fifth, especially through public election campaigns have the opportunity to obtain much information about the various policies and problems facing the nation and state in realizing the welfare of its citizens.

In order for the general election to be a means for the realization of a political life that is dermkratis, in its implementation must be accompanied by several requirements as follows. First, the general election should be held regularly and in the atmosphere of political life that allows the parties to compete in a healthy way: Second, the elections are organized by an agency outside the governmental power so as not to cause controversy resulting in widespread allegations against the organizers favoring one political party. Third, political parties have equal opportunity to access and build direct communication with the community. Without these requirements, elections are very easily accused as tools to manipulate and mobilize people's power in the interests of the ruling elite.

Elections are an important part of institutions in modern democracies, as it is well known that in a modern (generally indirect) democratic state there must be an organ called parliament or a popular parliament. Membership of this parliament is generally filled through elections. In the election all the people are given a chanceto elect his deputies who will sit in parliament and exercise authority over the interests of the people he represents.

The number of parliamentarians (commonly referred to as this legislative body) in each country varies depending on the number of people and / or area. Indeed, the basis of membership of this parliament is not always through elections but some are based on descent (such as the 
upper house in the UK) and based on appointment (as in Canada). But in general membership in the parliament is elected through an election with a party system. Elections with this party system mean that the people vote for the party, while the parties who become contestants in the General Election announce the names of candidates to become members of parliament.

There are generally two main systems and principles in this General Election:

1) Single-member constituency (an electoral district has a representative), commonly called a district system.

2) Multi-member constituency (an electoral district chooses several representatives), usually called a balanced Representative system

\section{District System}

The district system is determined on the basis of geographic entity in which each geographical referred to the district selects only a representative. In this system the state must divide its territory into a large number of districts and the number of districts is equal to the number of MPs. The party that gets the most votes in each district is entitled to fill the parliamentary seat of the district concerned so that the nominee of the party that gets the most votes is the MP. The votes obtained by other parties (which are not the most) are wasted because no matter how many votes there will be no representation in parliament since the contested seat is one. Countries like Arnerika, England, Canada and India use this district system. Some of the weaknesses and virtues of the district system can be noted.

a. Weaknesses:

1) it does not take into account minor parties and minorities, especially if the members of the small and minority parties are divided into several districts. In such circumstances small parties and minorities are difficult to get elected representatives.

2) is less representative because the losing candidates in one district are losing their supporting voices so that the supporters have no representation in parlernen.

\section{b. Advantages :}

The small district border allows the candidate to be selected:

1) well known by the voters.

2) the district system encourages the integration of political parties because the seats are contested only one for each district so as to obtain the most votes some political parties usually gather in one container.

3) the decline of political parties further facilitates a stable government (integration).
4) system, it is simple and easy to implement.

\section{Balanced Representative System (Proportional)}

The central idea of this system is that the number of seats one party earns matches the number of votes obtained. In this system the territory of the state is also divided into regions, but the boundaries are greater than the area in the district system. Each region selected a number of representatives according to the population. For example, for every 400,000 inhabitants there must be a representative if area A has 1-200,000 inhabitants, this area A will have a representative person, every 400,000 votes is rewarded with one parliamentary seat. Thus, in this system every vote is counted so that nothing is lost. Excess votes from the satay quota in an area can be compensated with the advantages in other areas. This proportional system is often also combined with a flat system (list system) in which voters choose a list of candidates or one party that has created a list of candidates for members that are ranked by rank.

Some of the disadvantages of this proportional system can be noted as follows:

a. facilitate the pragmentation and the emergence of new parties. This system does not facilitate the integration effort of the various trends that exist within the community.

b. the elected representative is more attached to the party and less loyal to the area he represents because of the more prominent party than the representative's personality.

c. the number of partals can complicate the formation of a stable government because it usually has to base the dirt on a coalition of two or more parties.

The state government formed through elections is a state government that grows and originates according to the will of the people and is used according to the will of the people, by the people, according to the system of deliberation and representation. Such a state government will have the authority (charisma) and who are able to maintain the noble humanitarian character and retain the moral characteristics as a civilized nation. The government of the country formed through elections willto be a government that prioritizes people's welfare visas, as it gets the majority support (legitimacy) from the people.

General Election is a means to realize the state life order in accordance with the basic state and the 1945 Constitution, and in line with the ideals of the proclamation of independence August 17, 1945, the arrangement of life order was implemented through general elections. Elections aim to elect people's representatives (not party representatives) to sit in the deliberative bodies and representatives of the people, form governments, continue the struggle for independence, and always maintain the unity of the Unitary State of the Republic of Indonesia. 
Therefore, the election is not justified to cause damage to the joints and order of life of the people, nation and nation. For that purpose, in the election exercise must seriously pay attention to and implement the basic principles of the elections themselves, namely the determination of candidates must be open (involving the broadest possible political participation), the candidate's legitimacy must be high enough against constituents (the voters), there is accountability between the representatives and constituents, the practicality of the vote counting process and the determination of eligibility, the enforcement of justice legislation in legal certainty.

The essence of free and fair elections is the right to exercise rights and freedoms, free from discrimination based on race, color, sex, language, religion, nationality or social origin, birth or other status. wealth, political opinion or anything else. This standard is found in every international human rights instrument.

The non-discriminatory standard applies in the aspects of the election process, and the selection of electoral districts. to the requirements and registration of voters, party and candidate qualifications, allocation of election resources, and other measures to the counting of votes and reports of election results. This standard also directly relates to equal rights before the law, the right to equal legal protection, and the right to receive effective remedies for violations of human rights. These rights relate to the enforcement of appropriate or effective legislation or election laws, with effective complaints mechanisms, and with the search for justice to an independent judiciary.

\section{Conclusion}

Election as one of the efforts to overcome the problems of the nation that is experiencing a multidimensional crisis is an effective means for state pemenggaroan. In a democratic system, elections are important because they will demonstrate the democratic structure and political processes of a country's political system. A country can not be said to be democratic if its political system is not based on democratic elections. Elections are a fundamental component of the democratic policymaking system that gives citizens choice to choose candidates, programs and policies, and participating political parties as contestants.

In addition to functioning to provide legitimacy to the government, parliament and the polical system itself, elections are also closely related to the issue of mandate, namely the rights granted to parliamentarians and the government, as well as the process of political communication. In order for the political communication process to succeed then it takes a public trust. Steps should be taken to ensure that the electoral process is not only administratively correct but must also be free of a one-sided impression. It is therefore important for governments and election organizers to take more efforts than simply fulfill legal requirements in order to create the expectation that justice choices should be upheld.

The course of elections must be in accordance with the principle of elections that are clearly defined by the 1945 Constitution. Election organizers (KPU) should avoid errors that can harm citizens, so that citizens feel not harmed and political rights are not violated. The government must guarantee the right of citizens to vote and take action against human rights violations in the election.

\section{REFERENCES}

[1] Bagir Manan, Mewujudkan Kedaulatan Rakyat Melalui Pemilu, Gaya Media Pratama, Jakarta, 1999.

[2] Bintan R. Saragih, Lembaga Perwakilan dan Pemilihan Umum di Indoenesia, Gaya Media Ptratama, 1988.

[3] Coliver, S. \& P. Merloe. 1994. Guidelines for Election Broadcasting in Transitional Democracies (London: Article 19)

[4] CST., Kansil dan Christine ST., Kansil,Ilmu Negara (Umum dan Indonesia). Jakarta: Pradnya Paramita, 2001.

[5] Garber, L. Establishinga Legal Frame work for Elections" and "Election Commissions: Responsibilities and Composition (Washington, D-C.. NDI), 1992.

[6] Hans Kelsen, General Theory of Law and State, Russel \& Russel, New York, 1972.

[7] J. Kristiadi, Menyelenggarakan Pemilu yang Bersifat Luber dan Jurdil, Center for Strategic and International Studies (CSIS), Jakarta, 1997.

[8] Maurice Duverger, Teori dan Praktek tata Negara, Pustaka Rakyat, Jakarta, 1961.

[9] O'Malley, P. Uneven Paths: Advancing Democracy in Africa (Washington, D.C.: NDI), 1993.

[10] Stoddard, M. Considerations for Creation, Organization and Implementation of Electoral Systems [an Outline, (Washington, D.C.. NDI) 1994.

[11] United Nations Centre for Human Rights, Professional Training Series No. 2, Human Rights and Elections (New York: U.N., ISSN 1020-1688), 1994. 